modeling in conducting scientific research is emphasized and it is noted that currently the problem of modeling of the system of future psychologists' science preparation in higher education institutions has not found its place in scientific researches.

In accordance with the outlined goal and tasks, a theoretical analysis of literary sources related to the problem of modeling the various aspects of science preparation was conducted; the concept of "model of future psychologists' science preparation system in higher education institutions" is specified and components of the developed model are characterized.

It is stated that characteristics of organizational-purpose, conceptual-methodological, structural-content, process-technological and diagnostical-effective blocks of the developed by us model of system of future psychologists science preparation in higher education institutions, which we consider as a holistic composition of generalized, structured, are presented, logically agreed and interrelated theoretical and methodological foundations of science preparation, which serve as an algorithm for successful achievement of the set goal and developed by us pedagogical conditions of its realization (the ability of sciences discipline teachers demonstrate functional polyvector nature of science preparation, taking into account professional orientation; transformation of the content of science disciplines to prepare future psychologists taking into account the modern achievements in the field of neuroscience and the needs of future professional activity; organization of educational process of science preparation on the basis of innovation) will lead to improvement of science preparation in higher education institutions, and in future in case of practical implementation of the model of future psychologists' science preparation system, will contribute to the highly qualified professional activity of future psychologists, their competitiveness at the labor market and enable them to engage in science.

Key words: model, pedagogical conditions, science preparation, future psychologists, higher education institution.

УДК 159.923

Валентина Блохіна

Університет імені Альфреда Нобеля (Дніпро) ORCID ID 0000-0001-5719-7068

DOI 10.24139/2312-5993/2019.08/170-179

\title{
СТРУКТУРА ГОТОВНОСТІ ПРАКТИЧНИХ ПСИХОЛОГІВ ДО ДІЯЛЬНОСТІ 3 РОЗВИТКУ ПРОФЕСІЙНОї ГРУПИ
}

У статті представлено аналіз проблеми готовності практичних психологів до діяльності з розвитку профресійної групи. На основі узагальнення досліджень науковців виокремлено функції практичного психолога, який працює в конкретній організації. Представлено визначення поняття «готовність майбутніх практичних психологів до розвитку професійної групи». Схарактеризовано особливості діяльності психологів у галузі організаційної психології. Визначено структуру готовності до професійної діяльності практичного психолога в організації. Схарактеризовано компоненти готовності практичних психологів до діяльності в галузі організачійної психології загалом та розвитку групи зокрема. Доведено особливу роль комунікаційного компоненту готовності практичного психолога до роботи з професійною групою.

Ключові слова: практичний психолог, професійна група, організаційна психологія, готовність, структура, компоненти. 
Постановка проблеми. Оновлення суспільства, що виявляється в соціальних реформах, зміні філософії побуту та праці, впливі інформаційних потоків на сучасну людину, пришвидшує ритм ії життя і стає джерелом постійного стресу. Такий стан речей спричиняє появу активного інтересу до професії психолога, основною роллю якого пересічний громадянин вважає допомогу в життєвій орієнтації, виокремленні стратегічних та тактичних планів, вирішенні проблем, пов'язаних із порушенням психологічного комфорту. Однак, за досить однозначним уявленням масової свідомості про сутність праці психолога особливості його діяльності виявляються залежно від завдань, виокремлених у конкретних професійних галузях. Зрозуміло, що психолог у закладі дошкільної освіти і психолог у організації з надзвичайних ситуацій виконує не однакові функції.

В умовах ринкової економіки актуалізується проблема конкуренції у професійних середовищах, тож цінності для організації набуває практичний психолог, здатний створити комфортні психологічні умови не лише для діяльності працівників, але й для розвитку підприємства в цілому (через вплив на мотивацію до розвитку кожного члена колективу). Для ефективного менеджменту, що змушений здійснювати управління в умовах конкуренції на ринку, набуває важливості проблема не лише оптимізації бізнес-процесів, але й взаємин співробітників організації, що розглядаються як основний ресурс у досягненні успіху бізнесу. Отже, сучасний підприємець стає все більшою мірою зацікавленим у співпраці із психологом, що відбувається не тимчасово, а на постійній основі.

Аналіз актуальних досліджень. Сучасні науковці досить активно досліджують проблему застосування фахівцями-психологами прикладних умінь у сфері корпоративних бізнесів. Найбільш популярним можна вважати визначення функціональних компетенцій психологічної служби в організації, зокрема інформаційної, консультативної, регулятивної, діагностичної, дидактичної, пропагандистської, профілактичної, корекційної, психотерапевтичної та реабілітаційної (С. Герасіна, 2019). Л. Карамушка ефективність діяльності організаційного психолога пов'язує із допомогою адміністрації організації здійснити професійний відбір кадрів, організацією та проведенням релаксації працівників за важких стресогенних умов праці, науковою організацією праці, психологічною сумісністю й адаптацією працівників, розподілом праці й функцій між співробітниками, лімітуванням часу на професійну діяльність і відпочинок, оформленням робочих місць в організації тощо (Карамушка, 2005).

Сучасні фахівці відносять діяльність організаційного психолога до одного з видів консалтингових послуг - інтелектуальні послуги (консультаційні, прикладні), що пов'язані із вирішенням складних проблем у сфері управління організації (Hebert Dieter, 2006), зокрема психологічний аспект слід ураховувати в організації маркетингових програм, інноваційної діяльності, пошуку шляхів виходу з кризових ситуацій тощо. 
С. Герасіна завдання організаційного психолога пов'язує з вирішенням першопричинних і вузлових проблем підприємства, які впливають на «оздоровлення» організації. У компетенцію психолога, на думку автора, входять конкретні дії: організація та постановка маркетингу на підприємстві; консалтинг (консультування) з питань реклами та PR (public relations - зв'язки з громадськістю); піар-компанія (посилення привабливості фірми в очах клієнтів, партнерів, конкурентів тощо); командоутворення (формування командної взаємодія за допомогою психотехнологій сучасного менеджменту та груподинамічних технік); корпоративна культура (формування системи цінностей, переконань, традицій і норм поведінки працівників, що є потужнім інструментом командоутворення та конкурентоспроможності організації) (Герасіна, 2012, с. 172).

Узагальнення наукових доробок щодо змісту діяльності організаційного психолога дозволяє визначити основні завдання, покладені на нього в бізнес-структурах: розробку та провадження ефективної системи мотивації працівників; вивчення міжособистісних відносин та аналіз соціально-психологічних процесів; участь у проведенні співбесід для визначення особистісних та ділових якостей кандидатів; активація прихованого потенціалу кожного співробітника; проведення навчальних та мотиваційних тренінгів і семінарів.

Метою статті визначаємо аналіз структури та змісту готовності майбутніх практичних психологів до розвитку професійної групи.

Методи дослідження: аналіз наукових джерел, узагальнення результатів дослідження.

Виклад основного матеріалу. У визначенні структури готовності практичного психолога до професійної діяльності цінними вважаємо результати дослідження Н. Чепелєвої, що представлені у вигляді моделі особистості практикуючого психолога зі складовими:

-мотиваційно-цільова підструктура особистості передбачає сформовану позитивну мотивацію до професійної діяльності, надання психологічної допомоги, прийняття себе та інших. Базовою особистісною якістю на цьому рівні виступає діалогізм, що включає діалогічну готовність, безумовне сприйняття іншого, особистісну рефлексію, розвинену систему особистісних смислів, орієнтованість на досягнення взаєморозуміння;

-когнітивна підструктура, до якої належить сфера знань особистості: особистісне знання, знання себе та інших; Я - концепція фахівця (адекватність та сталість самооцінки, емпатичність, асертивність, відсутність хронічних внутрішньоособистісних конфліктів, що зумовлюють проекції та психологічні захисти тощо); професійно важливі якості пізнавальних процесів (уважність, спостережливість, уміння помічати деталі вербальної та невербальної поведінки, тобто розпізнавати психосоматичні стани, гнучкість, пластичність та динамічність мислення, уміння виділяти суттєве та узагальнювати, 
прогнозувати реакції та дії клієнта, моделювати результати роботи). Базовими особистісними якостями когнітивної підструктури $є$ професійна рефлексія та професійний інтелект;

•операційно-технологічна підструктура передбачає розвинену компетентність фахівця-психолога. Вона містить володіння основними професійними вміннями та навичками, що забезпечують практичне використання наявних теоретичних знань. Найважливішим компонентом цієї підструктури є практичний інтелект;

•комунікативно-рольова підструктура передбачає розвинену комунікативну компетентність психолога. Вона містить соціально-когнітивні та комунікативні вміння (слухати іншого, розмовляти та вмовляти, установлювати соціальний контакт, переконувати іншого, навіювати тощо). Ця підструктура включає також специфічні якості - акторські та режисерські, організаційні, що дозволяють ефективно впроваджувати активні психотехніки і групові засоби психокорекції. Базовою особистісною якістю $є$ професійна ідентифікація та соціальний інтелект. Остання - це здатність у процесі спілкування визначати будь-які відхилення від нормального функціонування або розвитку людини чи групи, яка є найважливішою складовою спеціальних здібностей до психологічної діяльності;

- регулятивна підструктура забезпечує толерантність до фрустрацій, високу працездатність і саморегуляцію особистості, відсутність схильності до збудження та швидкого виснаження. Провідним компонентом виступає професійна саморегуляція (Чепелева, 1998).

Слід визнати, що позитивною особливістю представленої науковцем структури готовності до професійної діяльності практичного психолога $є$ те, що особистісні якості, важливі для конкретної діяльності, додані до кожного компоненту (підструктури), а не виділені в окремий компонент. Така наукова позиція дозволяє розуміти професійну підготовку психологів у межах створеного повноцінного освітнього середовища.

Особливо важливим компонентом готовності практичного психолога до професійної діяльності слід визнати комунікативний компонент, оскільки зазначена професія вимагає від фахівця спрямованості на комунікацію, причому психолог має навчитись, перш за все, активно слухати клієнта. Н. Бачманова та Н. Стафуріна виокремлюють такі складові «таланту спілкування»:

-здібності до повного та правильного сприйняття об'єкта, спостережливість, швидка орієнтація в ситуації;

-розуміння внутрішніх властивостей та особистостей об'єкта, проникнення в його внутрішній світ, психологічна інтуїція, які засновані на глибокій загальній ерудиції та гуманістичній спрямованості;

•здатність до співпереживання, емпатія, доброта, повага до людини, готовність допомогти; 
- здатність до самоаналізу, інтерес до власної особистості й особистості інших людей;

- здатність управляти самим собою та процесом спілкування, уміння бути уважним, тактовним, уміння слухати, установлювати контакт, викликати довіру, мати почуття гумору (Бачманова, 1985).

у дослідженні Н. Перегончук переконливо доведено, що комунікативна компетентність $€$ основним показником готовності психолога до професійної діяльності. Водночас зазначена компетентність містить певні особливості порівняно із загальною комунікативною компетентністю будь-якого фахівця, що виявляються: у спрямованості майбутнього психолога на спілкування з актуалізацією альтруїстичної установки та високого рівня емпатії; інтелектуальних здібностях, які дозволяють здійснювати конструктивне спілкування, ототожнене науковцем із соціальним інтелектом (здатністю правильно розуміти і прогнозувати поведінку інших людей, розпізнавати їхні наміри, почуття, емоційні стани за вербальною та невербальною експресією); соціальній фасилітації - здатності психолога впливати на суб'єктів (на вербальному, невербальному та паралінгвістичному рівнях) (Перегончук, с. 499).

Оскільки діяльність практичного психолога в організації щільно пов'язана з управлінською діяльністю керівника, цікавим у зазначеному аспекті вважаємо дослідження С. Стеблюк, у якому авторка в межах професійної компетентності фахівців підприємства визначає психологокорекційний компонент, обґрунтовуючи свій вибір вимогами адаптації фахівця до вимог європейського простору, зокрема пріоритетами в мотивації досягнення успіхів у професійній діяльності, адаптації, мобільності, здатності до самоконтролю та самоаналізу (Стеблюк, 2019). Таким чином, підкреслюємо, що певним чином психологічний аспект можна вважати чинником готовності до професійної діяльності керівника, тоді як організаційний аспект, більшою мірою визнаний як елемент професіограми адміністратора, стає важливим також і в підготовці організаційного психолога.

Отже, готовність до професійної діяльності практичного психолога $\epsilon$ досить складним структурованим утворенням, яке формується на основі набуття студентами знань із загальної психології та особливих компетенцій, що дозволятимуть здійснювати діяльність у сфері практичного застосування психологічного знання (за видом діяльності).

Узагальнення наукових підходів до змісту підготовки психологів загалом та виокремлення особливостей підготовки практичних психологів зокрема, характеристика особливостей діяльності психологів у галузі організаційної психології, а також визначення структури готовності до професійної діяльності практичних психологів дозволило визначити та схарактеризувати компоненти готовності практичних психологів до діяльності в галузі організаційної психології загалом та розвитку групи зокрема: 
Мотиваційний компонент - виявляє рівень мотивації до професійної діяльності практичного психолога; його спрямованість мотивувати до успіху кожного члена професійного колективу та групи в цілому; уміння мотивувати членів професійної групи до активності в діяльності, саморозвитку; спрямованість на діалогізм у взаємодії з членами колективу та керівником; цінність людської особистості.

Когнітивний компонент - виявляє сформованість загальнопсихологічних знань, знань із психології групи, мотивації особистості в діяльності, знання особливостей Я-концепції особистості фахівця.

Операційно-технологічний компонент - свідчить про сформованість професійних умінь та навичок застосування знань: визначення та застосування в діяльності із групою конкретних технологій впливу на особистість та колектив; дидактичні вміння (едукація працівників та керівника); діагностично-проектувальні вміння; уміння створювати комфортний психологічний клімат; здійснювати психологічний супровід розвитку колективу; забезпечувати умови для адаптації нових членів колективу.

Комунікативний компонент - виявляє сформованість комунікативних умінь: активного слухання, підтримки бесіди, ії корекції; уміння комунікативного впливу (переконання, умовляння, навіювання); уміння встановлювати соціальний контакт; використання психотехнік та засобів психокорекції у комунікації.

Рефлексивний компонент - визначає готовність до ціннісного компромісу; сформованість уміння розпізнавати ризики порушення стабільності організації (законсервованість або надмірну плинність кадрів); виявляти елементи (поведінкові реакції) незадоволеності працею працівників. Зауважуємо, що у змісті рефлексивного компоненту ми орієнтувалися на те, що саме має навчитися робити майбутній психолог в аспекті професійної діяльності з розвитку групи, а не на його особисту рефлексію щодо готовності до професійної діяльності. Уважаємо, що саме таке бачення змісту зазначеного компоненту дає найбільш повне уявлення про зміст структури готовності психолога до діяльності з розвитку професійної групи в цілому.

Уважаємо, що зміст кожного із визначених компонентів є неповним без визначення якісних особистісних утворень, сформованість яких свідчить про природну готовність майбутнього психолога організовувати розвиток професійної групи. У такій авторській думці орієнтувалися на наукову позицію Н. Чепелевої, яка в кожному компоненті структури готовності практичного психолога до професійної діяльності представила, крім знань та компетентностей, ще й особистісні якості, важливі для здійснення конкретної діяльності (Чепелева, 1998).

Зважуючи на вищезазначене, представляємо зміст кожного компоненту готовності практичних психологів до діяльності з розвитку професійної групи, узагальнені в таблиці 1. 
Таблиця 1

Структура готовності практичних психологів до діяльності з розвитку професійної групи

\begin{tabular}{|c|c|c|}
\hline Компоненти & Зміст (знання, компетенції) & Зміст (особистісні якості) \\
\hline Мотиваційний & $\begin{array}{l}\text { мотивація до професійної діяльності } \\
\text { практичного психолога; } \\
\text { здатність мотивувати до успіху } \\
\text { кожного члена професійного } \\
\text { колективу та групи в цілому; } \\
\text { уміння мотивувати членів } \\
\text { професійної групи до активності в } \\
\text { діяльності, саморозвитку; } \\
\text { спрямованість на діалогізм у } \\
\text { взаємодії з членами колективу та } \\
\text { керівником; } \\
\text { цінність людської особистості }\end{array}$ & $\begin{array}{l}\text { моральність } \quad \text { (дотримання } \\
\text { морального } \\
\text { психолога); } \\
\text { конфіденційність; } \\
\text { корпоративна етичність }\end{array}$ \\
\hline Когнітивний & $\begin{array}{l}\text { загальнопсихологічні знання; } \\
\text { знання з психології групи; } \\
\text { знання з мотивації особистості в } \\
\text { діяльності; } \\
\text { знання особливостей Я-концепції } \\
\text { особистості фахівця }\end{array}$ & $\begin{array}{l}\text { професійно важливі якості } \\
\text { пізнавальних процесів: } \\
\text { уважність; } \\
\text { спостережливість (уміння } \\
\text { помічати вербальні та } \\
\text { невербальні реакції } \\
\text { працівників, розпізнавати } \\
\text { психосоматичні прояви); } \\
\text { гнучкість мислення }\end{array}$ \\
\hline $\begin{array}{l}\text { Операційно- } \\
\text { технологічний }\end{array}$ & $\begin{array}{l}\text { уміння та навички застосування } \\
\text { знань: визначення та застосування в } \\
\text { діяльності з групою конкретних } \\
\text { технологій впливу на особистість та } \\
\text { колектив; } \\
\text { дидактичні вміння (едукація } \\
\text { працівників та керівника); } \\
\text { діагностично-проектувальні вміння; } \\
\text { уміння створювати комфортний } \\
\text { психологічний клімат; } \\
\text { уміння здійснювати психологічний } \\
\text { супровід розвитку колективу; } \\
\text { уміння забезпечувати умови для } \\
\text { адаптації нових членів колективу }\end{array}$ & $\begin{array}{l}\text { організованість; } \\
\text { цілеспрямованість; } \\
\text { здатність до співпраці; } \\
\text { методичність; } \\
\text { наполегливість; } \\
\text { толерантність }\end{array}$ \\
\hline Комунікативний & $\begin{array}{l}\text { комунікативні вміння: активного } \\
\text { слухання, підтримки бесіди, ії } \\
\text { корекції; } \\
\text { уміння комунікативного впливу } \\
\text { (переконання, } \\
\text { навіювання); } \\
\text { уміння встановлювати соціальний } \\
\text { контакт; } \\
\text { уміння використання психотехнік та } \\
\text { засобів психокорекції у комунікації }\end{array}$ & $\begin{array}{l}\text { організаційні якості; } \\
\text { акторські якості; } \\
\text { соціальний інтелект; } \\
\text { емпатія; } \\
\text { доброта; } \\
\text { повага до людини; } \\
\text { готовність допомогти; } \\
\text { тактовність; } \\
\text { почутя гумору; } \\
\text { соціальна фасилітація }\end{array}$ \\
\hline
\end{tabular}


Педагогічні науки: теорія, історія, інноваційні технології, 2019, № 8 (92)

\begin{tabular}{|l|lr|l|}
\hline Рефлексивний & готовність до ціннісного компромісу; & спостережливість; \\
уміння розпізнавати ризики & критичність; \\
порушення стабільності організації & гнучкість \\
(законсервованість або надмірну & \\
плинність кадрів); & елементи \\
уміння виявляти & реакції) & \\
(поведінкові & працею & \\
незадоволеності & \\
\hline
\end{tabular}

Висновки. Аналіз структури та змісту готовності майбутніх практичних психологів до розвитку професійної групи дозволив сформулювати зазначене поняття як складне утворення, що виявляється у сформованості професійних знань та компетенцій 3 організаційної психології та здатності здійснювати психологічну едукацію керівника та працівників колективу, психологічну мотивацію до розвитку та професійної активності кожного члена групи, психологічний супровід розвитку професійного колективу.

Основними професійними якостями, які сприяють реалізації психолога в галузі організаційної психології, визначаємо моральність, гнучкість мислення, здатність до співпраці, комунікативність, соціальний інтелект та соціальну фасилітацію.

Перспективи подальших досліджень вбачаємо у з'ясуванні особливостей тімбілдингу як платформи підготовки майбутнього практичного психолога до розвитку професійної групи.

\section{ЛITEPATУPA}

Бачманова, Н. В., Стафурина Н.А. (1985). К вопросу о профессиональных способностях психолога. Сборник научных трудов «Современные психолого-педагогические проблемы высшей школы», 5, 62-67 (Bachmanova, N. V., Staphurina, N. A. (1985). To the issue of the psychologis's professional abilities. Collection of Scientific Papers "M odern Psychological and Pedagogical Problems of Higher Education", 5, 62-67).

Геберт, Д., Розенштиль, Л. (2006). Организационная психология. Харьков: Гуманитарный центр (Hebert, D., Rosenstil, L. (2006). Organizational psychology. Kharkiv: Humanitarian Center).

Герасіна, С.В. (2012). Специфіка консультаційної діяльності організаційного психолога. Міжнародний науковий форум: соціологія, психологія, педагогіка, менеджент, 165-175. Режим доступу: file:///C:/Users/3671 1/AppData/Local/Temp/Mnf_2012 9_25.pdf (Herasina, S. V. (2012). Specificity of consulting activity of organizational psychologist. International Scientific Forum: Sociology, Psychology, Pedagogy, Management, 165 - 175. Retrieved from: file:///C:/Users/3671 1/AppData/Local/Temp/Mnf 20129 25.pdf).

Карамушка, Л. М. (2005). Психологічний аналіз особливостей діяльності конкурентоздатної управлінської команди освітньої організації. збірник наукових праць Ін-ту психології імені Г. С. Костюка АПн України «Актуальні проблеми психології». Том 1 «Організаційна психологія. Економічна психологія. Сочіальна психологія», 16, 28-42 
(Karamushka, L. M. (2005). Psychological analysis of the peculiarities of the activity of a competitive management team of an educational organization. Collection of scientific works of the G. S. Kostiuk Institute of Psychology, Academy of Pedagogical Sciences of Ukraine "Actual problems of psychology". Volume 1 "Organizational Psychology. Economic psychology. Social Psychology", 16, 28-42).

Перегончук, Н.В. Комунікативна компетентність майбутніх психологів. Режим доступу: http://www.appsychology.org.ua/data/jrn/v10/i23/50.pdf (Peregonchuk, N.V. Communicative competence of future psychologists. Retrieved from: http:// www.appsychology.org.ua/data/irn/v10/ i23/50.pdf).

Стеблюк, С. (2019). Зарубіжний досвід формування професійної компетентності в майбутніх фахівців з підприємства в закладах вищої освіти. Педагогічні науки: теорія, історія, інноваційні технології, 1 (85), 180-191 (Stebliuk, S. (2019). Foreign experience of professional competence formation in future specialists from the enterprise in higher education institutions. Pedagogical sciences: theory, history, innovative technologies, 1 (85), 180-191).

Чепелєва, Н.В. (1998). Теоретичне обґрунтування моделі особистості практичного психолога. Збірник наук. праць НПУ імені М.П. Драгоманова «Психологія», Вип. III, 35-41 (Chepeleva, N. V. (1998). Theoretical substantiation of the model of the personality of a practical psychologist. Collection of Scientific works of NPU named after M .P. Drahomanov. "Psychology", Iss. III, 35-41).

\section{PEЗЮME}

Блохина Валентина. Структура готовности практических психологов к деятельности по развитию профессиональной группы.

В статье представлен анализ проблемы готовности практических психологов к деятельности по развитию профессиональной группы. На основе обобщения исследований ученых выделены функции практического психолога, который работает в конкретной организации. Представлено определение понятия «готовность будущих практических психологов к развитию профессиональной группы». Охарактеризованы особенности деятельности психологов в области организационной психологии. Определена структура готовности к профрессиональной деятельности практического психолога в организации. Охарактеризованы компоненты готовности практических психологов $к$ деятельности в области организационной психологии в общем и развития группы в частности. Доказана особенная роль коммуникационного компонента готовности практического психолога к работе с профессиональной группой.

Ключевые слова: практический психолог, профессиональная группа, организационная психология, структура, компоненты.

\section{SUMMARY}

Blokhina Valentyna. Structure of readiness of practical psychologists for activities on a professional group development.

The article focuses on the analysis of the issue of readiness of practical psychologists for activities on a professional group development. On the basis of the scientific works, generalization of the functions of a practical psychologist who is employed in a certain organization is given, namely, development and introduction of an effective system for employees' motivation; studying the interpersonal relations and analyzing social and psychological processes; participating in business interviews and identifying personal and business characteristics of the candidates; activating the hidden potential of each employee; carrying out educational and motivational trainings and seminars. 
The definition of the concept of "readiness of practical psychologists for activities on a professional group development" is given as a complex formation, which is manifested in developed professional knowledge and competence in the organizational psychology and ability to perform psychological education of the leader and the members of the group, psychological motivation for the professional development and professional activities of each member of the group, psychological support for the professional group development.

The scientific approaches to the content of the psychologists' training are generalized, in particular, the specific features of practical psychologists' training are distinguished. The special aspects of psychologists' activities in the field of organizational psychology are characterized. The structure of the readiness of practical psychologists for the professional activities in the organization is defined. The components of readiness of practical psychologists for the activities in the field of organizational psychology in general and, in particular, for the group development are characterized, namely, motivational, cognitive, operational and technological, communicative, reflexive. The special role of the communicative component of the readiness of practical psychologists for the activities with a professional group is proved, which is manifested in the commitment of the future psychologist to communication and actualization of altruistic orientation and a high level of empathy; intellectual abilities allowing to have an effective communication; social facilitation, i.e. ability of the psychologist to influence the subjects.

Key words practical psychologist, professional group, organizational psychology, preparedness, structure, components.

удк 374

Галина Бобрицька

Харківський національний автомобільно-дорожній університет ORCID ID 0000-0003-2793-5108

Ірина Клімова

Харківський національний автомобільно-дорожній університет ORCID ID 0000-0003-1965-8577

Олег Пташний

Харківський національний автомобільно-дорожній університет ORCID ID 0000-0001-6123-7253 DOI 10.24139/2312-5993/2019.08/179-189

\section{УРАХУВАННЯ ВІКОВИХ ОСОБЛИВОСТЕЙ ДОРОСЛИХ ЛЮДЕЙ ПІД ЧАС

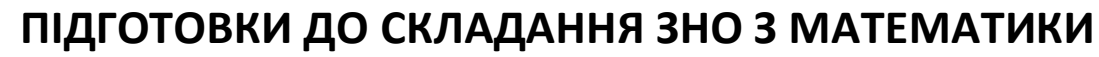

у роботі розглянуто основні аспекти підготовки дорослих людей до складання тестів зовнішнього незалежного оцінювання з математики, які включають як психологічну, так і математичну підготовку. На основі досвіду підготовки дорослих людей до тестів минулих років було розроблено програмумінімум для абітурієнтів. Ця програма містить мінімальний набір формул, які необхідно вивчити напам'ять. У статmі представлено орієнтовний план 